\title{
Application of organic matter fractionation technique for evaluation of coagulation-biofiltration process at a full scale WTP
}

\author{
[Tihomirova K., Gruškeviča K., Mežule L., Juhna T.]
}

\begin{abstract}
Biofilters at water treatments plants (WTP) are responsible for biologically stable water, but their effectiveness can be influenced by various factors. To determine the efficacy of the biofiltration process, so-called, natural organic matter (NOM) fractionation technique can be used, which enables the evaluation of distribution between hydrophobic and hydrophilic organic groups. Additionally, several methods were used for determination of living microorganisms in biomass of biofilters. The results of the current study showed that the biodegradation and biological activity processes in biofilters at WTP do not occur. The live microorganisms represented only $28 \%$ of the total cell count, which was $50 \%$ than reported. Nevertheless, NOM fractionation methods used in this research can be easily applied and useful for evaluation of full scale biofilter activity.
\end{abstract}

Keywords—biofilters, biomass, biostability, fractionation

\section{Introduction}

Due to relatively cold climate and abundance of soils and pits rich in organic carbon, the concentration of natural organic matter (NOM) in Latvia is higher than in many European countries [1]. During water disinfection NOM forms toxic and carcinogenic by-products and easily biodegradable organic carbon compounds (low molecular weight organic substances) which serve as a substrate for water microorganisms $[1,2,3]$.

To control the removal of NOM during water treatment not only the total concentration of organic substances but also their composition should be known. For example, organic substances with a high concentration of aromatic groups - mostly humic substances, are usually removed during coagulation [4], whereas biologically degradable organic carbon (BDOC) is better removed during biological filtration [5]. Nevertheless, simple classification into humic substances and BDOC is not always informative for water treatment plans with high NOM in raw water.

In order to optimize coagulation and biofiltration processes at WTP it is necessary to evaluate not only the total organic carbon concentration, but also the specific fraction distribution after each water treatment process. To determine the efficacy of the biofiltration process so-called natural organic matter fractionation methods can be used in combination with several other methods for determination of living microorganisms in the biomass of biofilters. The fractionation of NOM allows to evaluate the distribution of the high and low molecular weight (or hydrophobic and hydrophilic) organic groups.

Tihomirova Kristina., Gruškeviča Kamila, Mežule Linda., Juhna Talis

Riga Technical University, Building Centre

Latvia
The aim of this study was to characterize biofilter efficacy with rapid NOM fractionation technique in a fullscale water treatment plant located in Latvia and using humic rich raw water source for production.

\section{Materials and Methods}

\section{A. Water sample collection}

The WTP (supplying approximately $100000 \mathrm{~m}^{3} / \mathrm{d}$ and located in Riga, Latvia) takes the raw water from the River Daugava. The water has low turbidity and and high content of organic matter. The water is treated with preozonation (1-3 mg/l), chemical coagulation (average dose of 7-10 mg Al/1, $\mathrm{pH}$ 6.7-7.2), rapid sand filtration, main ozonation $(2-8 \mathrm{mg} / \mathrm{l})$ and biologically active carbon (BAC) filtration. The empty bed contact time (EBCT) of biofilter is 20-30 min. Finally a chlorine gas $(0.5-1.0 \mathrm{mg} / \mathrm{l}$ of free chlorine) is added for disinfection. The samples were collected every week for the period of one month during the cold season (from 21.11.2013 to 16.12.2013) from all the treatments steps of Daugava WTP in Riga, Latvia.

\section{B. TOC and dissolved organic carbon (DOC) determination}

TOC and DOC measurements were performed using a TOC-5000A Analyser and autosampler ASI-5000 (Shimadzu Corporation, Kyoto, Japan) based on high temperature and acidification of the sample and by the difference of the total carbon and inorganic carbon measurement, according to the standard method [6]. For DOC determination samples were filtered through $0.45 \mu \mathrm{m}$ pore size membrane filters (Millipore Corporation, USA). Each sample was tested in duplicate and the mean values were calculated $(\mathrm{CV} \leq 2 \%)$. The blank and control solutions were analyzed with each series of sample in order to verify the accuracy of the results obtained by the method. The minimal detection limit (MDL) was $380 \mu \mathrm{g} / 1$.

\section{NOM structure analysis}

The NOM structure analysis was performed according to the procedure described by Chow et al. [7]. The sample (500 $\mathrm{ml}$ ) filtered through a $0.45 \mu \mathrm{m}$ membrane was acidified to pH 2 with concentrated $\mathrm{HCl}$ and passed through the column with adsorbent resin DAX-8. A sample from column effluent $(60 \mathrm{ml})$ was collected for the DOC analysis and the remaining effluent was passed through the column with adsorbent resin XAD-4. The very hydrophobic acids (VHA) and slightly hydrophobic acids (SHA) were determined as 
the difference between the initial and effluent DOC from DAX-8 and XAD-4 columns, respectively. The effluent from XAD-4 was adjusted to $\mathrm{pH} 8$ with $10 \mathrm{M} \mathrm{NaOH}$ and passed through a column packed with adsorbent resin IRA958. The charged hydrophilic acids (CHA) were determined as the difference between the initial and effluent DOC from IRA-958 column. Finally, neutral (NEU) fraction was determined as the DOC concentration of IRA-958 effluent.

\section{Total bacterial counts}

Biofilter material samples were obtained from two randomly selected biofilters. Biofilter media samples were treated with ultrasonic processor (2 minutes at $20 \mu \mathrm{A}$ and $22 \mathrm{KHz}$, Cole Parmer) and then fixed with 3-4\% formaldehyde for at least 20 minutes. Then the sample $(0.1-0.5 \mathrm{ml})$ was filtered onto 25-mm-diameter $\quad 0.2-\mu \mathrm{m}$-pore-size filters (Anodisc; Whatman plc) and washed with $50 \mathrm{ml}$ of sterile distilled water. Without removing the membrane from the filtration unit, the sample was stained with $10 \mu \mathrm{g} / \mathrm{ml}$ DAPI (4', 6-diamidino-2phenylindole, Merck, Germany) for 15 - 20 minutes in the dark. Then the stain was removed by washing with $50 \mathrm{ml}$ of sterile distilled water. After washing the sample was removed from filtration unit and air-dried. Cell numbers were determined by epifluorescence microscopy by counting 20 random fields of view (Ex: 340/380 nm; Em. > $425 \mathrm{~nm}$, dichromatic mirror $565 \mathrm{~nm}$, Leica DM6000B). The results were expressed as amount of cells per $g$ of sample.

\section{E. Heterotrophic plate counts}

Decimal dilutions of samples (treated with ultrasound as for determination of total bacteria count) were performed in sterile distilled water and then inoculated onto R2A agar (Oxoid Ltd, UK) plates by spread plate technique. All plates were incubated in dark at $22^{\circ} \mathrm{C}$ for 7 days. The results were expressed as colony forming units (CFU) per ml of sample.

\section{F. Flow cytometry analysis}

Biomass samples were stained with $10 \mu \mathrm{l} / \mathrm{ml}$ SYBR Green I (Invitrogen, USA) dye (1:100 diluted with DMSO, (Sigma-Aldrich, USA)) and were kept in the dark for 15 minutes. To determine the cell counts CyFlow instrument (Partec, Hamburg, Germany) equipped with $200 \mathrm{~mW}$ laser, emitting a fixed wavelength of $488 \mathrm{~nm}$, and volumetric hardware was used. Green fluorescence (FL1) was collected at $640 \mathrm{~nm}$, red fluorescence (FL3) at $650 \mathrm{~nm}$ and all data were analyzed with the Flomax software (Partec). All samples were processed at speed $500 \mu \mathrm{l} / \mathrm{min}$. Unless stated otherwise, the instrument settings and electronic gates were kept the same for all samples in order to achieve comparable data.

\section{Results and discussions}

The average concentration of total organic carbon

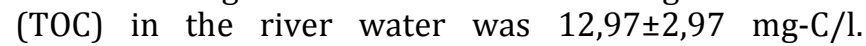
Dissolved organic carbon represented 88-99\% $(11,86 \pm 1,88 \mathrm{mg}-\mathrm{C} / \mathrm{l})$ of TOC. NOM at the source consisted mainly of the VHA and SHA factions (data not showed), which are mostly hydrophobic humic substances. During the treatment the average TOC concentration decreased from 12.97 to $6.57 \mathrm{mg} / \mathrm{l}$ and DOC from 11.86 to $6.62 \mathrm{mg} / \mathrm{l}$.

Water treatment significantly reduced the VHA faction (59\%). During the ozonation-coagulation and rapid sand filtration VHA fraction decreased from 5.19 to $0.89 \mathrm{mg} / \mathrm{l}$ and increased again to $0.98 \mathrm{mg} / \mathrm{l}$ after biofilters. Combination of ozonation process with biological treatment has the advantage on reduction of biological regrowth, because biological treatment can remove biologically active organic matter selectively [8]. Ozone is breaking high molecular weight organic matter into low molecular weight organic matter, this way increasing the biodegradability of NOM [8], but this process is slow. Due to the decrease of the size of the molecules, ozonation may also have negative effect on the NOM adsorption on BAC [9]. Significant increase of CHA fraction concentration (from 24\% to 35\%) after ozonation and NEU fractions (from 14 to $31 \%$ ) after the rapid sand filters were observed.

For the characterisation of NOM removal during biofiltration, the samples were collected before and after biofilters of Daugava WTP. The Results showed that the reduction in DOC concentration in the biofilters is low (4\% the biodegradable fraction of the DOC). The average DOC concentration in the biofilter inflow water samples was 6.99 $\mathrm{mg} / \mathrm{l}$ and in outflow - $6.62 \mathrm{mg} / \mathrm{l}$. CHA concentration decreased from $2.88 \mathrm{mg} / 1$ to $2.66 \mathrm{mg} / \mathrm{l}$, and at the same time NEU substance concentration decreased from $2.04 \mathrm{mg} / \mathrm{l}$ to $1.93 \mathrm{mg} / \mathrm{l}$. Thus, NOM fractionation results showed that VHA/NEU fractions did not change during BAC filtration process. Only transformation of SHA/CHA fraction occurred. This means that mineralization (transformation to $\mathrm{CO}_{2}$ ) of organic matter did not occur in the biofilters. The low efficacy of the biofilters may be linked to the high residual concentration of ozone $(0.31 \mathrm{mg} / \mathrm{l})$ and low temperature during the sample period. The water temperature in biofilter outflow samples was $14.0{ }^{\circ} \mathrm{C}$ in week $1,11.0^{\circ} \mathrm{C}$ in week $2,5.2^{\circ} \mathrm{C}$ in week $3,3.5^{\circ} \mathrm{C}$ in week $4,3.6{ }^{\circ} \mathrm{C}$ in week 5 . The results of the fractionation in the biofilter outflow samples can be seen in Fig 1. When the temperature of water was the lowest (week 4 and 5) the $\mathrm{CHA}$ fraction increased during the biofiltration process. Possibly the flushing of previously adsorbed CHA took place.

The rapid fractionation techniques appeared to be useful approach to monitor water treatment efficacy of NOM in humic rich waters

The amount of microorganisms in biomass of the biofilters was determined using several methods. Results showed that total cell count determined by DAPI method was $8.27 \times 10^{9}$ cells/ $1 \mathrm{~g}$ of filter material; living microorganisms as determined by flow cytometry analysis was $2.33 \times 10^{9}$ cells $/ 1 \mathrm{~g}$ of filter material and the colony forming units $-1.17 \times 10^{9}$ cells $/ 1 \mathrm{~g}$ of filter material, representing $28 \%$ 
and $14 \%$ of the total count accordingly. The biofilm on the filter material was distributed evenly and the average microbial count was $2.27 \times 10^{9}$ cells $/ 1 \mathrm{~g}$ of filter material in the upper layer of the filter, and $2.15 \times 10^{9}$ cells $/ 1 \mathrm{~g}$ of filter material at $1 \mathrm{~m}$ depth. The amount of viable microorganisms in the upper layer of the filter is less than $27 \%$, at a depth of $1 \mathrm{~m}-38 \%$. At the same time cultivable microorganism counts in the top filter layer is higher $(16 \%$ of the total count) than at $1 \mathrm{~m}$ depth - $10 \%$. The observed differences can be explained by the negative effect of the ozonation (viable counts) and starvation in the lower layers of the biofilters (cultivable counts).

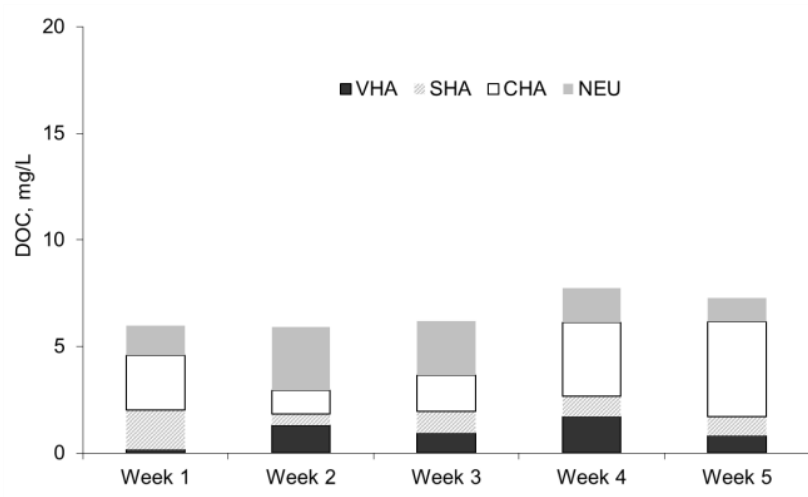

Figure 1. Changes of DOC fraction in outflow from biofilter during the experimental period.

During the study it was found that the average cell count in biomass isolated from biofilters was $5.66 \times 10^{9}$ cell per 1 $\mathrm{g}$ of filter material. Viable microorganism fraction consisted of only $28 \%$ of the total cell count. This is $50 \%$ lower than previously reported results [10].

So, low efficiency of the biofilters may be linked to the high residual concentrations of ozone before biofilters (average concentration of $0.31 \mathrm{mg} / \mathrm{l}$ ) and low water temperature $\left(3.5^{\circ} \mathrm{C}\right)$, which was identified during this study.

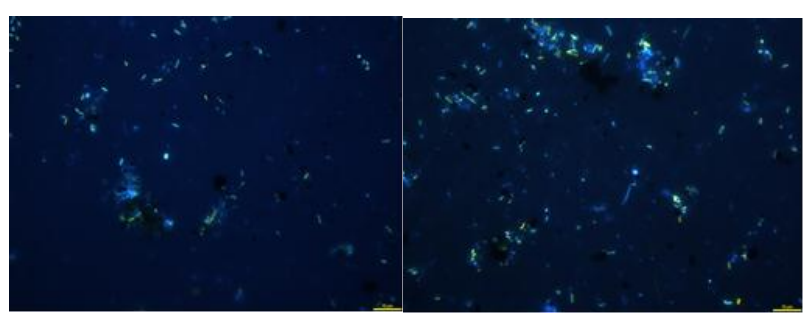

Figure 2. Biofilm of the biofilters captured with a fluorescen microscope (Ex: 340/380 nm; Em. > $425 \mathrm{~nm}$, dichromatic mirror $565 \mathrm{~nm}$, Leica DM6000B): biofilter 1 (left, $0.1 \mathrm{ml}$ ) and biofilter 2 (right, $0,1 \mathrm{ml}$ )

Analyses of the biofilm samples using DAPI method (Figure 2) showed that biofilter biomass cells form clusters with small particles of the filter material. All samples contained a lot of fluorescent inorganic particles, which interfered with the counting process. Samples from the $1 \mathrm{~m}$ depth represent much greater cell species diversity - small, shaped and very long cells, but their total number is lower than in the upper layer samples.

\section{Conclusions}

The rapid fractionation techniques appeared to be useful approach to monitor water treatment efficacy of NOM in humic rich waters.

The average DOC concentration in the biofilter inflow water samples was $6.99 \pm 0.90 \mathrm{mg} / \mathrm{l}$ and outflow $-6.62 \pm 0.79$ $\mathrm{mg} / \mathrm{l}$. CHA concentration decreased from $2.88 \mathrm{mg} / \mathrm{l}$ to 2.66 $\mathrm{mg} / \mathrm{l}$, and at the same time NEU substance concentration decreases from $2.04 \mathrm{mg} / \mathrm{l}$ to $1.93 \mathrm{mg} / \mathrm{l}$

The average plate count biological filter material is $5.66 \times 10^{9}$ cells per $1 \mathrm{~g}$ of the filter material. The amount of viable microorganisms was only $28 \%$ from the total cell count.

\section{Acknowledgment}

This work was supported by Latvian Council of Science Fund Project Z12.0491 "Smart biofiltration technology".

\section{References}

[1] Tihomirova K. "NOM Removal from Water and its Influence on the Drinking Water Quality: Natural organic matter removal from water and its influence on the water quality in distribution network", LAP LAMBERT Academic Publishing, ISBN: 978-3-8465-2340-7, 172 pages, 2011.

[2] Chen J., LeBoeuf E. J., Dai S., Gu B. "Fluorescence spectroscopic studies of natural organic matter fractions", Chemosphere, Vol. 50(5), pp. 639-647, 2003.

[3] Frimmel F.H. "Characterization of natural organic matter as major constituents in aquatic systems", Journal of Contaminant Hydrology, Vol. 35(1-3), pp. 201-216, 1998.

[4] Sharp E.L., Banks J., Billica J.A., Gertig K.R., Henderson R., Parsons S.A., Wilson D. and Jefferson B. "Application of zeta potential measurements for coagulation control: pilot-plant experiences from UK and US waters with elevated organics", Water Supply, Vol. 5, pp. 49-56, 2005

[5] Carlson G., Silverstein J. "Effect of molecular size and charge on biofilm sorption of organic matter", Water Research, Vol. 32(5), pp. 1580-1592, 1998.

[6] Water analysis - Guidelines for the determination of total organic carbon (TOC) and dissolved organic carbon (DOC), International Organization for Standardization, ISO 1484:2000.

[7] Chow C.W.K., Fabris R., and Drikas M. "A rapid fractionation technique to characterize natural organic matter for the optimization of water treatment processes", Journal of Water Supply: Research and Technology - AQUA, Vol. 53(2), pp. 85-92, 2004.

[8] Fahmi, Nishijima W., and Okada O. "Improvement of DOC removal by multi-stage AOP-biological treatment", Chemosphere, Vol. 50(8), pp. 1043-1048, 2003.

[9] Nishijima W., Speitel G.E.Jr. "Fate of biodegradable dissolved organic carbon produced by ozonation on biological activated carbon", Chemosphere, Vol. 56(2), pp. 113-119, 2004.

[10] Fonseca A.C., Summers R.S., and Hernandez M.T. "Comparative measurement of microbial activity in drinking water biofelters", Water Research, Vol. 35(16), pp. 3817-3824, 2001.

About Author:

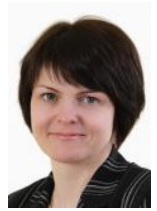

Kristina Tihomirova received her Ph.d. at the Riga Technical University. She is a senior researcher in RTU in the department of Water Engineering and Technology. Her main research interests are: drinking water treatment, drinking water quality, water treatment processes optimization, biofiltration technologies, wastewater treatment. 